\title{
Preconditioning with oil mixes of high ratio Omega-9:Omega-6 and a low ratio Omega-6:Omega-3 in rats subjected to brain ischemia/reperfusion ${ }^{1}$
}

\author{
Pré-condicionamento com misturas de óleos com Ômega-9:Ômega-6 (alta relação) e \\ Ômega-6:Ômega-3 (baixa relação) em ratos submetidos à isquemia/reperfusão cerebral
}

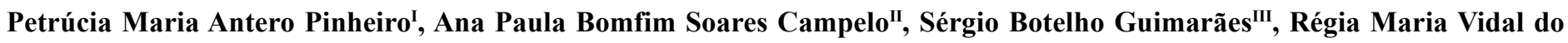 \\ Patrocínio $^{\mathrm{IV}}$, José Telmo Valença Junior ${ }^{\mathrm{V}}$, Paulo Roberto Leitão de Vasconcelos ${ }^{\mathrm{VI}}$

\begin{abstract}
IFellow Master degree, Department of Surgery, Postgraduate Program, UFC, Ceara, Brazil. Technical procedures, acquisition and interpretation of data. The article is part of a master degree dissertation.

IFellow Master degree, Department of Surgery, Postgraduate Program, UFC, Fortaleza, Brazil. Helped with technical procedures and interpretation of data.

IIIPhD, Associate Professor, Department of Surgery, Head, LABCEX, UFC, Ceara, Brazil. Critical revision, manuscript writing.

${ }^{\mathrm{IV}}$ MS, Pathologist, Department of Pathology and Forensic Medicine, UFC, Ceara, Brazil. Technical procedures and interpretation of data.

${ }^{v} \mathrm{PhD}$, Associate Professor, Department of Pathology and Forensic Medicine, UFC, Ceara, Brazil. Critical revision and interpretation of data.

${ }^{\mathrm{V}} \mathrm{PhD}$, Associate Professor, Coordinator, Postgraduate Program, Department of Surgery, UFC, Ceara, Brazil. Tutor, responsible for conception,
\end{abstract} \\ design, intellectual and scientific content of the study, critical analysis, final approval of manuscript.
}

\begin{abstract}
PURPOSE: This study aimed to assess the effects of preconditioning with mixtures of oils containing high/low ratio of $\omega-6 / \omega-3$ and $\omega-9 / \omega-6$, respectively, in an experimental model of cerebral ischemia-reperfusion (I/R).

METHODS: Forty-two Wistar rats were randomly distributed into two groups: control $(n=24)$ and test ( $n=18)$. Control group was subdivided in 4 subgroups ( $\mathrm{n}=6$ ): G1: Sham-Water; G2: I/R-Water; G3: Sham-Isolipidic and G4: I/R-Isolipid. The animals received water or a isolipid mixture containing $\omega-6 / \omega-3$ oils ( $8: 1$ ratio) and $\omega-9 / \omega-6(0.4: 1$ ratio) by gavage for seven days. Test group included 3 subgroups (n=6) G5: I/R-Mix1, G: 6 I/R-Mix2 and G7: I/R-Mix3. Test group animals received oily mixtures of $\omega-6 / \omega-3$ (1.4:1 ratio) and $\omega-9 / \omega-6$ (3.4:1 ratio), differing only in source of $\omega-3$ : G5 (alpha-linolenic acid); G6 (alpha-linolenic, docosahexaenoic and eicosapentaenoic acids), and G7 (alpha-linolenic and docosahexaenoic acids). On day $7 \mathrm{I} / \mathrm{R}$ rats underwent cerebral ischemia with bilateral occlusion of common carotid arteries for 1 hour followed by reperfusion for 3 hours. G1 and G3 animals underwent sham operation. Concluded the experiment, animals were decapitated and their brains sliced for red neurons (RN) count in CA3 area of the hippocampus. Variables were compared using ANOVA-Tukey test.
\end{abstract}

RESULTS: The use of different mix preparations promoted a decrease in red cell count in all three groups (G5/G6/G7), compared with G2/G4, confirming the protective effect of different oil blends, regardless of $\omega-3$ source.

CONCLUSION: Pre-conditioning with mixtures of oils containing high ratio $\omega-6 / \omega-3$ and low $\omega-9 / \omega-6$ relationship protects brain neurons against I/R injury in an experimental model.

Keywords: Brain Ischemia. Reperfusion. Metabolism/drug effects. Oils. Cell Death. Rats.

\section{RESUMO}

OBJETIVO: Avaliar os efeitos do pré-condicionamento com misturas de óleos contendo relação alta/baixa de $\omega-6 / \omega-3$ e $\omega-9 / \omega-6$, respectivamente, em um modelo experimental de isquemia/reperfusão (I/R) cerebral.

MÉTODOS: Quarenta e dois ratos foram distribuídos aleatoriamente em dois grupos: controle ( $n=24)$ e teste ( $n=18$ ). Grupo controle foi subdividido em quatro subgrupos ( $\mathrm{n}=6)$ : G1: Sham-Água; G2: I/R-Água; G3: Sham-Isolipídico e G4: I/R-Isolipídico. Os animais receberam água ou uma mistura isolipidica contendo $\omega-6 / \omega-3$ óleos $(8: 1)$ e $\omega-9 / \omega-6(0,4: 1)$ por gavagem, durante sete dias. O grupo teste incluiu três subgrupos (n=6) G5: I/R-Mix1, G: 6 I/R-Mix2 e G7: I/R-Mix3. Animais do grupo teste receberam de misturas de óleos $\omega-6 / \omega-3(1,4: 1)$ e $\omega-9 / \omega-6(3,4: 1)$, diferindo apenas na fonte de $\omega-3$ : G5:alpha-linolênico; G6: ácidos alpha-linolênico, eicosapentaenóico e docosahexaenóico e G7:ácidos alpha-linolênico e docosahexaenóico. No $7^{\circ}$ dia os grupos I/R foram submetidos à isquemia cerebral (1h) por oclusão bilateral das artérias carótidas comuns seguida de reperfusão (3h). Ratos G1 e G3 foram submetidos à operação simulada. Concluído o experimento, os animais foram decapitados e seus cérebros fatiados para contagem dos neurônios vermelhos na área CA3 do hipocampo. As variáveis foram comparadas pelo teste de ANOVA-Tukey.

RESULTADOS: A utilização de diferentes misturas de óleos promoveu uma diminuição na contagem de células vermelhas nos grupos G5/G6/G7, em comparação com G2/G4, confirmando o efeito protetor das misturas de óleos, independentemente da origem de $\omega$-3. 
CONCLUSÃO: O pré-condicionamento com misturas de óleos contendo alta proporção de $\omega-6 / \omega-3$ e baixa proporção de $\omega-9 / \omega-6$ protege os neurônios cerebrais da lesão de I/R em um modelo experimental.

Descritores: Isquemia Encefálica. Reperfusão. Metabolismo/efeitos de drogas. Óleos. Morte Celular. Ratos.

\section{Introduction}

When blood flow to the brain is reduced, survival of the tissue at risk depends on several modifying factors: the availability of collateral circulation, the duration of ischemia time and the intensity and speed of flow reduction ${ }^{1-3}$. These factors determine, in turn, the location and size of the lesion ${ }^{4}$. The changes caused by lack of blood supply to brain metabolic trigger cellular and molecular processes that induce self-destruction of neural cells ${ }^{5}$. Therefore, neuronal death can result from the combination of the processes of necrosis and apoptosis ${ }^{6-8}$. Cerebral tissue is particularly susceptible to the action of oxidating agents and therefore to ischemia-reperfusion injury ${ }^{9}$. Reperfusion after cerebral ischemia culminates in neuronal loss by apoptosis or cell necrosis ${ }^{10}$.

Several experimental models have been developed to mimic the structural and functional changes resulting from cerebral ischemia. Guides to the application of animal models for the study of cerebral ischemia have been published ${ }^{11-13}$. Animal models of cerebral ischemia can be classified into two categories: models of focal cerebral ischemia (occlusion of intracranial vessels, usually the middle cerebral artery) and models of global cerebral ischemia (occlusion of common carotid arteries and / or vertebral) ${ }^{14}$. Bilateral occlusion of common carotid arteries can produce partial transient global ischemia. The most significant metabolic changes were observed during the first minutes of reperfusion, characterized by the mobilization and use of energy substrates and consequent systemic overproduction of ATP, typifying the reperfusion injury ${ }^{15}$.

Fatty acids are organic molecules composed of atoms of carbon, hydrogen and oxygen. Mammals often use fatty acids obtained from the diet for their daily needs. However, when necessary, liver, adipose tissue and mammary glands are able to synthesize fatty acids (saturated and monounsaturated) from glucose and amino acids by means of specific enzymatic reactions ${ }^{16}$. Fatty acids frequently incorporated into membrane phospholipids are the $\omega-3$ eicosapentaenoic (EPA), and docosahexaenoic (DHA) acids, $\omega-6$ arachidonic acid (AA), and $\omega-9$ oleic acid $(\mathrm{OA})^{17}$. EPA and DHA have direct effects on the fluidity, the structure and function of cell membranes ${ }^{18}$. By incorporating the phospholipids of cell membranes, polyunsaturated fatty acids (PUFAs) influence immune and inflammatory responses acting on the fluidity of membranes (facilitating or hindering the adhesion receptors and surface molecules and production of enzymes), the synthesis of inflammatory modulators (eicosanoids and resolvins) and signal transduction, with greater or lesser production of inflammatory cytokines $^{19}$.

Ischemic preconditioning (IP) is the process in which a brief, sublethal ischemic insult protects tissue from a subsequent more severe ischemic lesions ${ }^{20}$. IP was first described in 1986 in an experimental model of intermittent coronary artery occlusion ${ }^{21}$. Ten years later the concept of ischemic preconditioning was applied to the brain ${ }^{22}$.

We hypothesize that preconditioning with fatty acid mixtures containing low ratio $\omega-6 / \omega-3$ and high ratio $\omega-9 / \omega-6$ may protect the cerebral tissues against ischemia-reperfusion injuries due to their anti-inflammatory and antioxidant properties.

\section{Methods}

Approval for experimental use of laboratory animals was obtained from the local Ethics Committee on Animal Use (CEUA, former CEPA) (protocol \#09/10, April 7, 2010). All surgical procedures and animal handling were conducted in accordance with the Brazilian Federal Law No. 11794 of October 8.2008 (http:/ /www.planalto.gov.br/ccivil_03/_Ato2007-2010/2008/Lei/ L11794.htm). The study was designed so as to minimize the number of animals required for the experiments. The animals were housed in polypropylene cages at ambient temperature of $24^{\circ} \mathrm{C}$ on a $12 \mathrm{~h}$ light-dark cycle. Rats were allowed free access to food (Purina chow) and tap water until the beginning of the experiment.

\section{Study design}

In this controlled experimental study, 42 male Wistar rats, weighing 260-290 g, were randomly distributed in two groups: Control $(n=24)$ and Test $(n=18)$. Control group was subdivided into four subgroups $(n=6)$ as follows: G1: Sham-Water; G2: I/R- Water; G3: Sham-Isolipidic and G4: IR-Isolipid. The animals received water or a isolipid mixture containing $\omega-6 / \omega-3$ oils $(8: 1$ ratio) and $\omega-9 / \omega-6$ (0.4:1 ratio) by gavage for seven days. Test group was divided into 3 subgroups $(n=6)$ G5: IR-Mix1, G6: IR-Mix2 and G7: IR-Mix3. Test group animals received oily mixtures of $\omega-6 / \omega-3$ (1.4:1 ratio) and $\omega-9 / \omega-6$ (3.4:1 ratio), differing only in source of $\omega-3$ : Mix1( $\omega-3$ alpha-linolenic acid); Mix2 ( $\omega$-3 alpha-linolenic, docosahexaenoic and eicosapentaenoic acids), and Mix3 ( $\omega-3$ alpha-linolenic and docosahexaenoic acids), administered by by gavage for seven days. Isolipid and Mix-1, Mix-2 and Mix-3 preparations are detailed on Tables 1 and 4.

TABLE 1 - Isolipid mixture composition. Corn oil

Soybean oil

\begin{tabular}{ll} 
ALA $(\omega 3)$ & $67.6 \mathrm{mg} / \mathrm{ml}$ \\
$\omega 6: \omega 3$ ratio & $8: 1$ \\
$\omega 9: \omega 6$ ratio & $0.4: 1$ \\
\hline $\begin{array}{l}\text { Isolipid mixture composition }=\text { corn and } \\
\text { soybean oils }\end{array}$
\end{tabular}


TABLE 2 - Composition of Mix 1.

\begin{tabular}{ll}
\hline Olive oil & \\
Canola oil & \\
Linseed oil & \\
Source $\omega 3$ & ALA $(100 \%)=116.7 \mathrm{mg} / \mathrm{ml}$ \\
$\omega 6: \omega 3$ ratio & $1.4: 1$ \\
$\omega 9: \omega 6$ ratio & $3.4: 1$ \\
\hline
\end{tabular}

Mix $1=+$ Olive + Canola + Linseed oils (ALA)

TABLE 3 - Composition of Mix 2.

\begin{tabular}{ll}
\hline Olive oil & \\
Canola oil & \\
Fish oil & \\
Source $\omega 3$ & ALA $(35 \%)+$ EPA $(39 \%)+$ DHA $(26 \%)$ \\
$\omega 6: \omega 3$ ratio & $1.4: 1$ \\
$\omega 9: \omega 6$ ratio & $3.4: 1$ \\
\hline
\end{tabular}

Mix 2 = Olive + Canola + Fish oil $($ ALA + EPA + DHA $)$

TABLE 4 - Composition of Mix 3.

\begin{tabular}{|c|c|}
\hline \multicolumn{2}{|l|}{ Olive oil } \\
\hline \multicolumn{2}{|l|}{ Canola oil } \\
\hline \multicolumn{2}{|l|}{ Linseed oil } \\
\hline Source $\omega 3$ & $\operatorname{ALA}(84 \%)+\operatorname{DHA}(16 \%)$ \\
\hline$\omega 6: \omega 3$ ratio & $1.4: 1$ \\
\hline$\omega 9: \omega 6$ ratio & $3.4: 1$ \\
\hline
\end{tabular}

On the seventh day, G1, G4, G5, G6 and G7 rats, anesthetized with a fresh-prepared mixture of ketamine $90 \mathrm{mg} \mathrm{kg}$ ${ }^{1}+x y$ lazine $10 \mathrm{mg} \mathrm{kg}^{-1}$ body weight injected intramuscularly, underwent cerebral ischemia with bilateral occlusion of common carotid arteries for 1 hour followed by reperfusion for 3 hours. G2 and G4 animals underwent sham operation. At the end of the experiment all animals were decapitated and their brains sliced for histopathological analysis of the area CA3 of the hippocampus. The slices $(5 \mu$ thick) of brain tissue of each rat were processed and stained with hematoxylin-eosin (HE) using conventional technique and analyzed by an experienced blinded pathologist. Neuronal death was quantified by red neurons (RN) counting.

\section{Statistical analysis}

Graphpad Prism 5.0 (GraphPad Software, San Diego,CA, USA, www.graphpad.com) was used for statistical analysis and graphics design. All data were tested for distribution (KolmorogovSmirnov test). Analysis of variance (ANOVA) associated with the multiple comparison test of Tukey was used for comparing three groups. The $t$ test for unpaired variables was used to compare two treatment groups. The level of statistical significance was set at $5 \%(\mathrm{p}<0.05)$.

\section{Results}

To confirm the effectiveness of the ischemia model, we compared the numbers of red neurons in the $\mathrm{C} 3$ area of the hippocampus of rats subjected to sham operation $(\mathrm{G} 1)$ and rats subjected to ischemia / reperfusion $(\mathrm{G} 2)$, using the t test for unpaired variables. G2 red neurons count decreased significantly compared with G1 (36.83 \pm 9.79 vs. $17.67 \pm 8.48$, $\mathrm{p}<0.01$ ) (Figure 1).

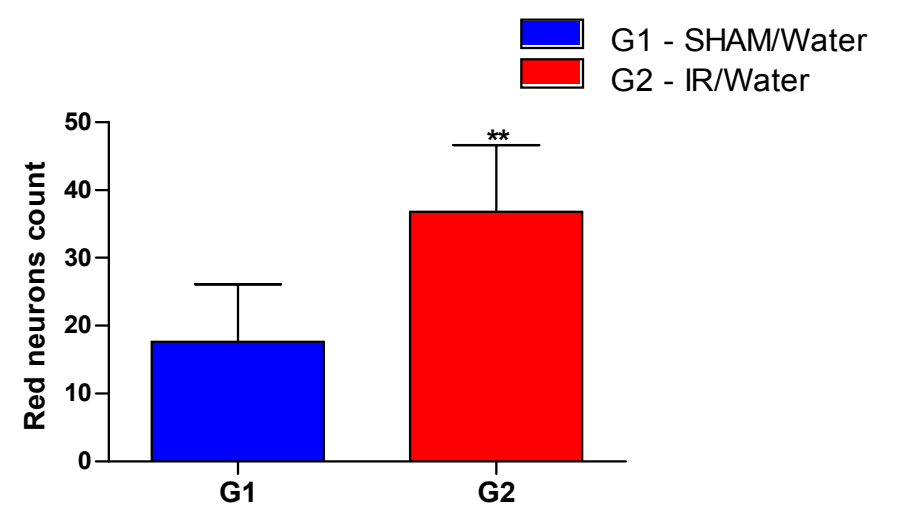

FIGURE 1 - Red neurons count in rats subjected to Sham procedure (blue bar) and Ischemia/Reperfusion (red bar), both treated with water. Bars represent mean $\pm \mathrm{SD}$ values in 6 rats. G2 red neurons count was significantly different from G1 by $t$ test.

$\mathrm{p}<0.01, \mathrm{G} 2 \mathrm{vs}, \mathrm{G} 1$.

Red neurons count values decreased significantly in G5 compared with G2 (36.83 \pm 9.79 vs. $12.33 \pm 6.31, \mathrm{p}<0.01)$ and G4 $(29.83 \pm 12.19$ vs. $12.33 \pm 6.31, \mathrm{p}<0.05)$ groups (Figure 2$)$.

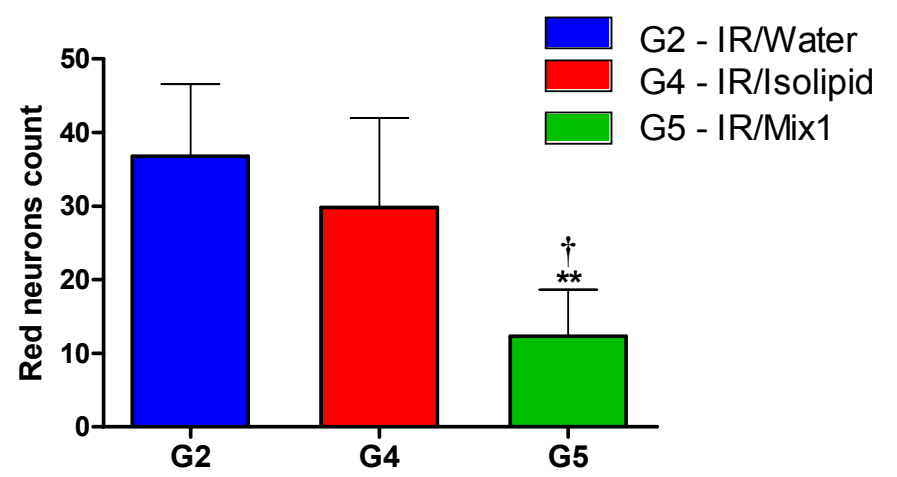

FIGURE 2 - Red neurons count in rats subjected to Ischemia/Reperfusion and treated with Water (blue bar), Isolipid (red bar) and Mix-1 (green bar) preparations. Bars represent mean $\pm \mathrm{SD}$ values in 6 rats. G5 red neurons count was significantly different from G2 and G4 groups by ANOVA - Tukey test.

$\dagger \mathrm{p}<0.05$, G5 vs. G4; **p<0.01, G5 vs. G2. 
Red neurons count values decreased significantly in G6 compared with G2 $(36.83 \pm 9.79$ vs. $10.67 \pm 2.81, * * * \mathrm{p}<0.001)$ and G4 (29.83 \pm 12.19 vs. $10.67 \pm 2.81, * * \mathrm{p}<0.01)$ (Figure 3$)$.

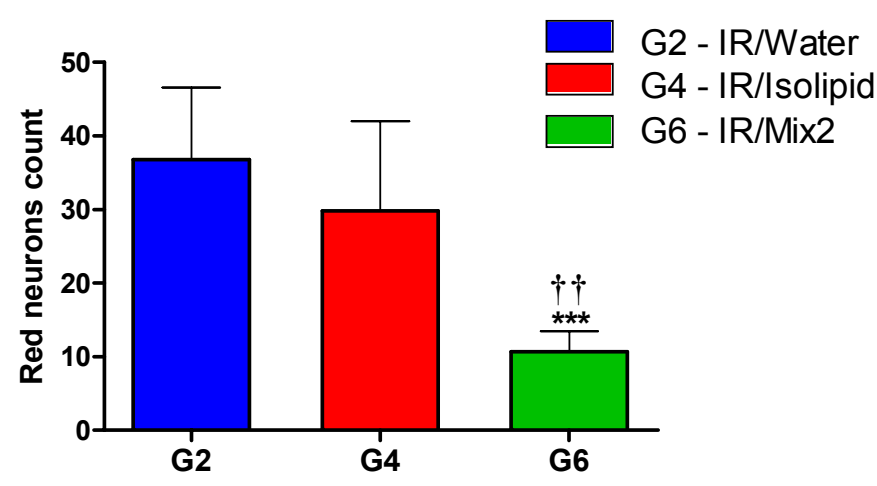

FIGURE 3 - Red neurons count in rats subjected to Ischemia/Reperfusion and treated with Water (blue bar), Isolipid (red bar) and Mix-2 (green bar) preparations. Bars represent mean $\pm \mathrm{SD}$ values in 6 rats. G6 red neurons count was significantly different from G2 and G4 groups by ANOVA - Tukey test.

$\dagger \mathrm{p}<0.01$, G6 vs. G4; ***p<0.001, G6 vs. G2.

Red neurons count values decreased significantly in $\mathrm{G} 7$ compared with G2 (36.83 \pm 9.79 vs. $7.33 \pm 6.47, \mathrm{p}<0.001)$ and $\mathrm{G} 4$ $(29.83 \pm 12.19$ vs. $7.33 \pm 6.47, \mathrm{p}<0.01)$ groups (Figure 4$)$.

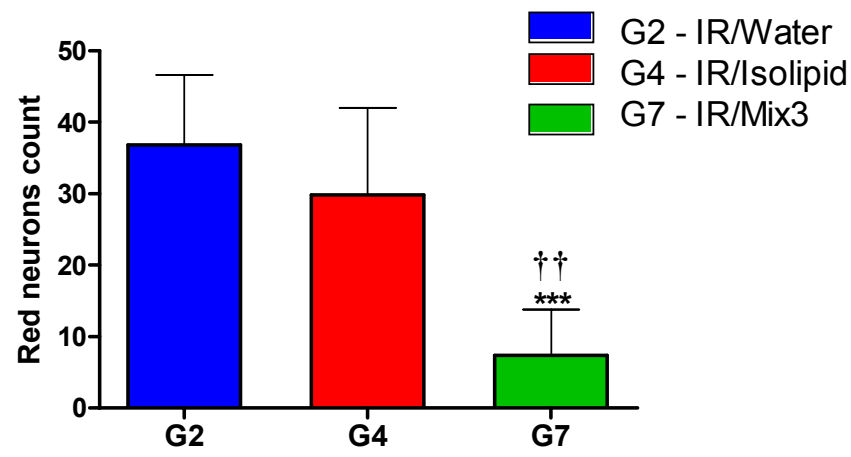

FIGURE 4 - Red neurons count in rats subjected to Ischemia/Reperfusion and treated with Water (blue bar), Isolipid (red bar) and Mix-3 (green bar) preparations. Bars represent mean $\pm \mathrm{SD}$ values in 6 rats. G6 red neurons count was significantly different from G2 and G4 groups by ANOVA - Tukey test.

$+p \mathrm{p}<0.01, \mathrm{G} 7$ vs. G4; *** $\mathrm{p}<0.001, \mathrm{G} 7$ vs. G2.

Red neuron count values were not different in test groups, treated with different mix preparations (Figure 5).

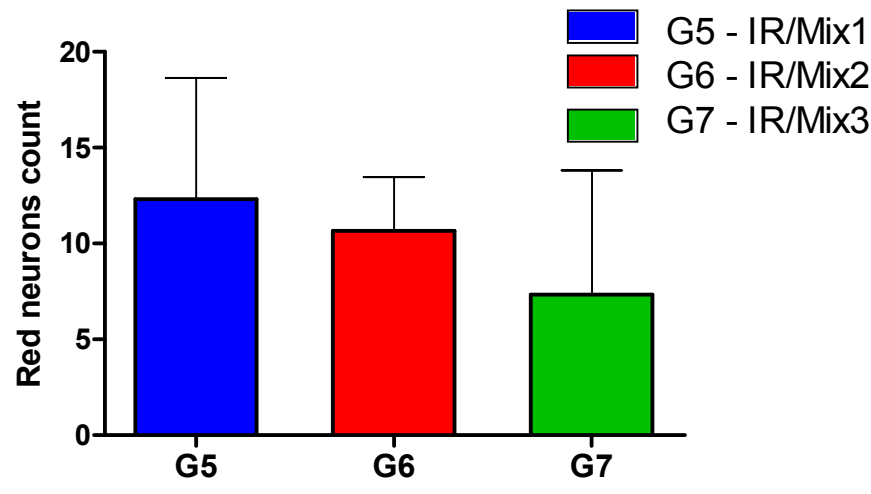

FIGURE 5 - Red neurons count in rats subjected to Ischemia/Reperfusion and treated with Mix-1 (blue bar), Mix-2 (red bar) and Mix-3 (green bar) preparations. Bars represent mean $\pm \mathrm{SD}$ values in 6 rats. Red neurons count was not different comparing all groups by ANOVA - Tukey test. †p $<0.01, \mathrm{G} 7$ vs. G4; ***p $<0.001, \mathrm{G} 7$ vs. G2.

Red neuron count values were not different in test groups, treated with different mix preparations (Figure 6).

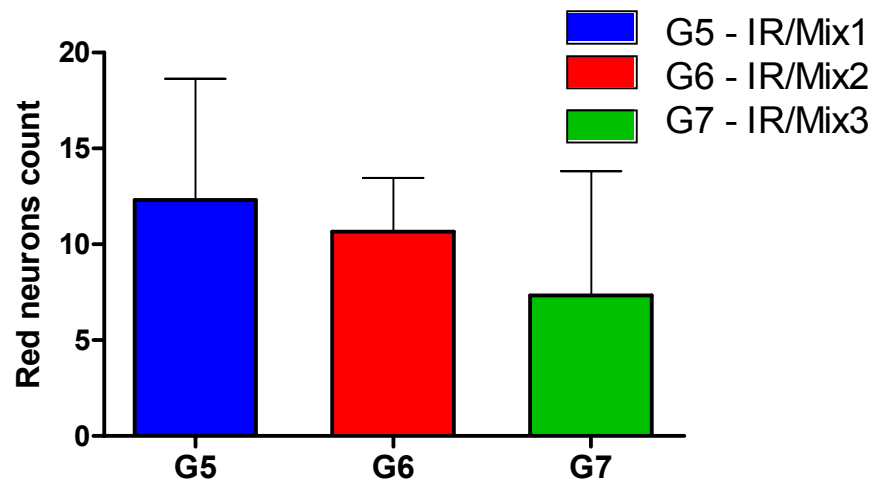

FIGURE 6 - Red neurons count in rats subjected to Ischemia/Reperfusion and treated with Mix-1 (blue bar), Mix-2 (red bar) and Mix-3 (green bar) preparations. Bars represent mean \pm SD values in 6 rats. Red neurons count was not different comparing all groups by ANOVA - Tukey test.

\section{Discussion}

Several experimental models have been used to study the changes induced by ischemia and I/R of the brain. The temporary occlusion of both common carotid arteries, used in this experiment, interferes with irrigation of most anterior-medial regions of the brain $^{23}$. Among the models of global cerebral ischemia with bilateral occlusion of common carotid arteries followed by reperfusion in rats, a review of the literature disclosed models 
where ischemia time ranged from 1 minute ${ }^{23}$ up to 2 hours $^{24}$ and reperfusion time ranging from 5 minutes $^{25}$ to 10 days $^{26}$. The model used in this study ( $1 \mathrm{~h}$ ischemia $+3 \mathrm{~h}$ reperfusion), using Wistar rats, appears to be unprecedented since there were no similar studies in the literature, currently.

The hippocampus has been described as a very susceptible region to delayed ischemic lesions, humans included ${ }^{27}$. The consequence of cerebral $\mathrm{I} / \mathrm{R}$ is a selective loss of vulnerable neurons in specific regions, such as the hippocampus, particularly in area $\mathrm{CA} 1^{3,10}$. While the CA1 neurons are highly vulnerable to ischemia, the hippocampus CA3 area seems to be more resistant to ischemic injury $^{28}$. Brain ischemia induces a variety of structural changes in affected neurons, which include: nuclear and cytoplasmic pallor ("ghost neuron"), shrinkage and condensation ("dark neurons"), nuclear pyknosis, cytoplasmic eosinophilia ("red neurons") and formaldehyde pigment precipitation, among others ${ }^{11}$.

In this work, mixtures of oils containing $\omega-3, \omega-6$ and $\omega-9$ fatty acids, were evaluated in a model of cerebral $I / R$ in rats. In the experiment we used three oil blends with nutraceutical potential, named "Mix 1, Mix 2 and Mix 3", and an isocaloric mixture of oils, with no nutraceutical potential named "Isolipidic", used as control. A second control group received only water. Both water and oil mixtures were administered via gavage for seven days. The administration of nutraceutical mixtures for 7 days before induction of ischemia-reperfusion characterized the nutritional preconditioning.

In first experiment we used a mixture of oils, named Mix 1, whose formulation was rich in $\omega-3$ (ALA) and relatively low in $\omega-6$. The group of rats that received a mix of oils showed an average red count significantly below the average red neurons counted on both control groups, showing a protective effect against neuronal damage from $\mathrm{I} / \mathrm{R}$, probably due to its anti-inflammatory and antioxidant properties. The presence of PUFAs $\omega-3$ and $\omega-6$ in tissues depends on the amount and type of dietary lipids and the activity of desaturase enzymes ${ }^{29}$. DHA is the major fatty acid in neuronal cells, and considering that mammals cannot synthesize DHA again, the composition of membranes is directly correlated with their nutritional intake ${ }^{30}$. In the second experiment a mixture of oils, called Mix2, containing ALA, EPA and DHA was used. The group of rats that received the Mix 2 had an average of red neurons count significantly lower than the average red neurons of both control groups, undoubtedly showing a protective action against neuronal damage from $\mathrm{I} / \mathrm{R}$. These results were similar to those verified in rats treated with Mix 1 preparation, whose formulation does not contain EPA or DHA, only ALA. Therefore, there was no advantage in the administration of EPA and DHA, compared to ALA.

Finally, in the third experiment an oil blend named Mix3 whose formulation included ALA and DHA extracted from algae oil was used. The group of rats that received the Mix 3 showed an average of red neurons significantly lower than the average of red neurons of both control groups, demonstrating its protective action against I/R injury of the brain. However, the group that received the Mix 3 showed an average of red neurons similar to groups that received either Mix 1 or Mix2. Considering all results it is clear that there were no differences in numbers of red neurons among groups Mix 1, Mix 2 and Mix 3.
Given the above, it is reasonable to conclude that this experimental model of $\mathrm{I} / \mathrm{R}$ injury led to extensive and intense neuronal injuries due to the large brain area involved in global ischemia, and prolonged periods of ischemia and reperfusion used here. All three mixtures of oils containing high ratio of fatty acids and low $\omega-9 / \omega-6$ relationship between $\omega-6 / \omega-3$ fatty acids exerted a protective effect against ischemia and reperfusion in experimental brain injury.

\section{Conclusion}

Pre-conditioning with mixtures of oils containing high and low ratio $\omega-6 / \omega-3$ and $\omega-9 / \omega-6$ relationship protects brain neurons against ischemia-reperfusion injury in an experimental model.

\section{References}

1. Miyasaka N, Nagaoka T, Kuroiwa T, Akimoto H, Haku T, Kubota T, Aso T. Histopathologic correlates of temporal diffusion changes in a rat model of cerebral hypoxia/ischemia. AJNR Am J Neuroradiol. 2000;21(1):60-6.

2. Schaller B, Graf R. Cerebral ischemia and reperfusion: the pathophysiologic concept as a basis for clinical therapy. J Cereb Blood Flow Metab. 2004;24(4):351-71.

3. Lehotský J, Burda J, Danielisová V, Gottlieb M, Kaplán P, Saniová B. Ischemic tolerance: the mechanisms of neuroprotective strategy. Anat Rec (Hoboken). 2009;292(12):2002-12.

4. Bederson JB, Pitts LH, Germano SM, Nishimura MC, Davis RL, Bartkowski HM. Evaluation of 2,3,5-triphenyltetrazolium chloride as a stain for detection and quantification of experimental cerebral infarction in rats. Stroke. 1986;17(6):1304-8.

5. Toldy A, Atalay M, Stadler K, Sasvári M, Jakus J, Jung KJ, Chung HY, Nyakas C, Radák Z. The beneficial effects of nettle supplementation and exercise on brain lesion and memory in rat. J Nutr Biochem. 2009;20(12):974-81.

6. Martin LJ, Al-Abdulla NA, Brambrink AM, Kirsch JR, Sieber FE, Portera-Cailliau C. Neurodegeneration in excitotoxicity, global cerebral ischemia, and target deprivation: A perspective on the contributions of apoptosis and necrosis. Brain Res Bull. 1998;46(4):281-309.

7. Liou AK, Clark RS, Henshall DC, Yin XM, Chen J. To die or not to die for neurons in ischemia, traumatic brain injury and epilepsy: a review on the stress-activated signaling pathways and apoptotic pathways. Prog Neurobiol. 2003;69(2):103-42.

8. Lo EH, Dalkara T, Moskowitz MA. Mechanisms, challenges and opportunities in stroke. Nat Rev Neurosci. 2003;4(5):399-415.

9. Fatokun AA, Stone TW, Smith RA. Adenosine receptor ligands protect against a combination of apoptotic and necrotic cell death in cerebellar granule neurons. Exp Brain Res. 2008;186(1):151-60.

10. Kiray M, Bagriyanik HA, Pekcetin C, Ergur BU, Uysal N. Protective effects of deprenyl in transient cerebral ischemia in rats. Chin J Physiol. 2008;51(5):275-81.

11. Garcia JH. Experimental ischemic stroke: a review. Stroke. 1984;15(1):5-14.

12. Liu S, Zhen G, Meloni BP, Campbell K, Winn HR. Rodent stroke model guidelines for preclinical stroke trials (1st Edition). J Exp Stroke Transl Med. 2009;2(2):2-27.

13. García-Bonilla L, Rosell A, Torregrosa G, Salom JB, Alborch E, Gutiérrez M, Díez-Tejedor E, Martínez-Murillo R, Agulla J, RamosCabrer P, Castillo J, Gasull T, Montaner J. Recommendations guide for experimental animal models in stroke research. Neurologia. 2011;26(2):105-10. 
14. Tardini, DMS, Yoshida WB, Novelli ELB, Sequeira JL. Avaliação de dois modelos experimentais de isquemia e reperfusão cerebral em ratos com oclusão temporária carotídea associada ou não à oclusão vertebral. Acta Cir Bras. 2003;18:514-7.

15. Muniz LRF, Faria MHG, Vasconcelos PRL de. Metabolic evaluation of ischemic and reperfusion brain injury following bilateral occlusion of common carotid arteries: an experimental study in rats. Acta Cir Bras. 2004;19(5):529-34.

16. Calder P. Long-chain n-3 fatty acids and inflammation: potential application in surgical and trauma patients. Braz J Med Biol Res. 2003;36(4):433-46.

17. Chan S, McCowen KC, Bistrian B. Medium-chain triglyceride and ômega-3 polyunsaturated fatty acid-containing emulsions in intravenous nutrition. Curr Opin Clin Nutr Metab Care. 1998;1(2):163-69.

18. Calder PC, Grimble RF. Polyunsaturated fatty acids, inflammation and immunity. Eur J Clin Nutr. 2002;56(Suppl 3):S14-9.

19. Waitzberg DL, Torrinhas, RS. Fish oil lipid emulsions and immune response: what clinicians need to know. Nutr Clin Pract. 2009;24(4):48799.

20. Stagliano NE, Pérez-Pinzón MA, Moskowitz MA, Huang PL. Focal ischemic preconditioning induces rapid tolerance to middle cerebral artery occlusion in mice. J Cereb Blood Flow Metab. 1999;19(7):757-61.

21. Murry CE, Jennings RB, Reimer KA. Preconditioning with ischemia: a delay of lethal cell injury in ischemic myocardium. Circulation. 1986;74(5):1124-36.

22. Pérez-Pinzón MA, Mumford PL, Rosenthal M, Sick T. Anoxic preconditioning in hippocampal slices: role of adenosine. Neuroscience. 1996;75(3):687-94.

23. Kunimatsu T, Asai S, Kanematsu K, Kohno T, Misaki T, Ishikawa K. Effects of glutamate receptor agonist on extracellular glutamate dynamics during moderate cerebral ischemia. Brain Res. 2001;923(1-2):178-86.

24. Iwasaki Y, Ito S, Suzuki M, Nagahori T, Yamamoto T, Konno H. Forebrain ischemia induced by temporary bilateral common carotid occlusion in normotensive rats. J Neurol Sci. 1989;90(2):155-65.
25. Faria MHG, Muniz LRF, Vasconcelos PRL de. Ketone bodies metabolism during ischemic and reperfusion brain injuries following bilateral occlusion of common carotid arteries in rats. Acta Cir Bras. 2007;22(2):125-9.

26. Heim C, Sieklucka M, Sontag KH. Levemopamil injection after cerebral oligemia reduces spatial memory deficits in rat. Pharmacol Biochem Behav. 1994;48(3):613-9.

27. Petito CK, Feldmann E, Pulsinelli WA, Plum F. Delayed hippocampal damage in humans following cardiorespiratory arrest. Neurology. 1987;37(8):1281-6.

28. Zola-Morgan S, Squire LR, Rempel NL, Clower RP, Amaral DG. Enduring memory impairment in monkeys after ischemic damage to the hippocampus. J Neurosci. 1992;12(7):2582-96.

29. Manku MS, Morse-Fisher N, Horrobin DF. Changes in human plasma essential fatty acid levels as a result of administration of linoleic acid and gamma-linolenic acid. Eur J Clin Nutr. 1988;42(1):55-60.

30. McNamara RK, Able J, Jandacek R, Rider T, Tso P, Eliassen JC, Alfieri D, Weber W, Jarvis K, DelBello MP, Strakowski SM, Adler CM. Docosahexaenoic acid supplementation increases prefrontal cortex activation during sustained attention in healthy boys: a placebo-controlled, dose-ranging, functional magnetic resonance imaging study. Am J Clin Nutr. 2010;91(4):1060-7.

\section{Acknowledgement}

We are in debt to Francisco Vagnaldo Fechine Jamacaru, $\mathrm{MD}, \mathrm{PhD}$, Visiting Professor of the Department of Pharmacology, IV, UFC, Fortaleza-CE, Brazil, for his helpful technical assistance with the statistical analysis of our results.

\section{Correspondence:}

Prof. Paulo Roberto Leitão de Vasconcelos

Rua Professor Costa Mendes, 1608/3 andar

60430-140 Fortaleza - CE Brasil

Tel.: (55-85)3366-8083

Fax: (55-85)3366-8064

paulo.vasconcelos@ufc.br

Conflict of interest: none

Financial source: none

${ }^{1}$ Research performed at Experimental Surgery Laboratory (LABCEX), Faculty of Medicine, Federal University of Ceara (UFC), Fortaleza-CE, Brazil. 